\title{
Japan's Ascent to the Status of Economic Superpower in a World System Perspective
}

JACQUES HERSH

\section{Introduction}

Although the term "miracle" has gained acceptance to describe the Japanese ascent to its present position in the world economy it can hardly be considered a scientific category. ${ }^{1}$ It will be recalled in this connection. that even an esteemed sociologist as Max Weber originally expressed doubts as to the prospects of capitalism in Japan. Nevertheless, in the course of little more than one century that country has become a leading capitalist nation; in economic terms second only to the United States.

This "Great Leap Forward" has shaken conventional wisdom as to societal development. While Western governments are presently looking for ways of restraining Japanese successes in international trade, on the academic level the process has turned Japan into a challenge: Economics, political science, anthropology, etc. -all have been mobilized to deal with this problematique. They offer valuable, if partial, explanations to the basic question of how it was possible for a country not belonging to the European cultural tradition to accomplish such a feat. ${ }^{2}$

Understanding the internal background is, of course, of primordial importance in conceptualizing the country's trajectory. Nevertheless, the argument can be made that a paramount factor allowing the domestic process to unfold was exceptional geopolitical circumstances. Indeed, extraordinary external conditions characterized Japan's situation from the very beginning of the West's intrusion into Asia. Compared to other nations of the area, Japan was given the historical opportunity to bring about an internal mobilization which allowed the country to escape the fate of direct or indirect colonialism. The reasons for this were numerous but related. Awareness of the dialectical relationship between the internal and the external elements behind Japan's transition to a modern nation-state has been a component of the Marxist or proto-Marxist tradition. ${ }^{3}$ In more recent time, any discussion of the transformation of defeated Japan into 
an economic superpower in the course of some thirty-five years or less remains incomplete unless the external dimension is taken into consideration.

In this paper, an attempt will be made to focus on the propitious international environment in the country's evolution. First, we shall look at the historical conditions particular for the region at the time of Japan's opening to the world. Secondly, the paper will discuss the relationship which emerged between the postwar American project of restructuring the international political economy on the one hand and the specific situation of Japan on the other. Lastly, to the extent that the original premisses on which US hegemony of the world capitalist system no longer obtain, conjectures will be made as to the adjustment problems this gives rise to. Both external factors and the internal evolution project Japan as a major world actor as we approach the new millenium.

\section{The Transition to Modernity and the International Environment}

The comparative advantages of Japan around the middle of the nineteenth century were of a negative nature: Paucity of natural resources and poverty of the people. Weaknesses which acquired the quality of attributes by restraining Western interest. As the historian of precapitalist Japan, E.H. Norman, has put it: "In comparison to the attractions and profits of the Chinese market, Japan had very little to offer either as a market for foreign manufactures or as a granary of raw materials for Western industry." Similarly, Western preoccupations with other areas of Asia such as Indonesia and China afforded Japan a certain respite. It was believed that the forceful opening of Japan would not be worth the effort. Under these circumstances, the Tokugawa feudal regime avoided coming under the domination of any imperialist power. The main source of Japanese anxiety during the first half of the nineteenth century was related to Russian ambitions. The geography factor, however, protected Japan from the Romanov Empire as the vast half-explored steppes of Siberia and the sea separated the two. Furthermore, as Russia became embroiled with Britain over the fate of Afghanistan and involvement in the Crimean War this land-based power's aspirations were correspondingly reduced. ${ }^{5}$ Internally, the evolution of Japan during the years of seclusion had given the ruling classes a certain ideological uniformity and a disciplined 
bureaucracy. The samurai caste gave Japan added strength. ${ }^{6}$ In addition, the population was relatively well educated with a high degree of cultural homogenity ${ }^{7}$ and a fairly developed basic infrastructure.

The rulers of Japan had nevertheless good reasons to be alarmed at the increasing activity and creeping attention to their country on the part of foreign navigators and empire-builders. Until the middle of the 1850s, the Russians made persistent but unsuccessful attempts to break Japan's seclusion. The first serious successes in »opening « Japan were made by the Russians and especially the Americans. At that time, however, the focus of interest was on China. Japan lay on the route to China for both powers. ${ }^{8}$ The expedition by Commodore Matthew Perry (1853/54) succeeded in forcing Japan to open its ports to American ships on their way to and from China for provisioning or repairs. Similar treaties were later signed with the Russians, the British, the French as well as other European powers.

The new arrival of the United States on the world scene and the growing rivalry between imperialist powers fulfilled the function of checks and balances on the freedom of action of each. Thus the leading nation, Britain, was prevented from establishing exclusive rights in China and turning the country into a colony as had been the case in India. It was also this international jealousy which made it difficult for any one Western nation to attempt a full-fledged conquest of Japan. This situation had a favorable impact on domestic Japanese developments. While intra-imperalist intrigues and conflicts complicated the international climate it presented Japan with an interlude to put its house in order and thus avoid the fate of other non-European nations. The transition from feudalism to capitalism was hastened by the impact of the foreign menace, adding urgency to the Meiji Reformation which sought to overcome the weaknesses of Japanese society caused by disunity and social disintegration. As Norman put it:

Taking advantage of this valuable breathing space, the Meiji leaders were able to destroy the feudal government of intrigue and dissension, setting up in its place a national, centralized government and opening Japan to the invigorating air of Western science and invention; and finally, through the foresight of this brilliant group of statesmen, the new regime laid the foundations for a strong independent nation thereby making invasion from abroad too dangerous or too uncertain an undertaking. ${ }^{9}$ 
Although the disintegration of feudal Japan was due principally to internal causes the evidence seems to indicate that the "opening" of the country following the imposition of unequal treaties contributed to accelerate the process of national integration and centralization of the society which is a precondition for capitalism. Fear of the West thus played a decisive role in an evolution which might otherwise have been longer and less intensive. On the ideological level, as Michio Morishima points out, a kind of "defensive nationalism" as a salient feature of Japanese Confucianism had originated as early as the fifth and sixth centuries on the basis of awareness of the cultural disparity with China. With contact to Western countries a similar trend came into force. ${ }^{10}$ Comparing this situation to examples where the transition to a modern society was held back, one may grasp the importance of the favorable circumstances Japan was offered by the fate of history. In the words of a French specialist:

"There can be no doubt that Japan's success in economic and military terms especially when contrasted with the failures of China, Spain, Turkey, Persia and so on was to a considerable extent due to her rapid transformation into a unified nation-state." ${ }^{11}$

Rising Japanese capitalism was nevertheless threatened on the one hand by the unequal treaties which had forced Japan to accept the import of foreign goods and on the other hand by the country's lack of natural resources. The former "advantages" which had made Japan less attractive to the imperialist powers were dysfunctional to the development of indigenous capitalism and resistance to foreign encroachment. These weaknesses had to be overcome were Japan to industrialize and retain independence. Meiji leaders understood the dilemma and linked the two aspects together in the proposed project of Fokuko-kyohei, that is the creation of "a rich nation with strong armed forces." In other words, a formula for a modern military system. In fact, driven by a strong sentiment of nationalism, the economic growth of the country became centrally directed with priority given to strategic industries such as iron, armament and shipbuilding. With the aim of resisting foreign competition the need for rapid development of an integrated industrial economy capable of supporting modern warfare was realized. In this connection gaining access to external natural resources was seen as a prerequisite and determinant for the role Japan was to play in East Asia. Geography (proximity) and history (the 
unsettled situation in the area) made such a course possible. As Norman noted: "The leaders of Meiji Japan saw no reason to abstain from the scramble for the partition of China, and if economic pressure, a narrow home market and scarcity of essential raw materials are to be considered as justification, Japan had more of it than the other powers." ${ }^{12}$

The struggle to become a recognized world power was successfully carried out. Its first consecration took place after the defeat of China during the 1894-95 war. Ostensibly the object of the conflict had been ChineseJapanese disagreement over the fate of Korea, but the war equally fulfilled an internal function by galvanizing the energies of the nation in the direction of favoring a greater role for Japan in the world. The frustration of the fruits of victory as a result of the so-called Triple Intervention (Russia, France, Germany) whereby Japan was forced to give up some of the concessions she had forced China to accept, resulted in making Japanese opinion hypersensistive to foreign intervention. Together with the gains made in spite of this interference -such as China's cession of Formosa and the Pescadores to Japan - it strengthened the hand of the political forces in favor of an active expansionist course. In geopolitical terms, the latecomer, Japan, now became an acknowledged member of the imperialist club. Thus Japanese troops participated in the suppression of the Boxer Uprising in China along with those of Western Powers. With the AngloJapanese Treaty of 1902, Japan was selected by Great Britain as the main bulwark against Imperialist Russia in Eastern Asia. The peace treaty of Porthsmouth, putting an end to the Russian-Japanese War (1904-05), established Japan as a major regional imperialist power. This conflict, as the Sino-Japanese War a decade earlier, was fought on Korean soil. This was a traumatic experience for the Korean nation and sealed its fate for the next forty years by linking it to the evolution of Japanese capitalism. Korea could no longer hope to play the imperialist powers against one another: China and Russia were now out of the picture.

But of greater significance for later developments was that the victory fueled support in Japan for the course of pursuing military and foreign expansion. An external factor pushing in the same direction was the inability or unwillingness of other powers to put a limit to Japanese ambitions. The opposite was in fact the case. Even before the end of the Russo-Japanese war, the American Secretary of War, William Howard Taft, had come to Tokyo in order to make a deal with Prime Minister Katsura. In exchange for American recognition of the seizure of Korea, the United States requested 
and received Japanese acceptance for its acquisition of the Phillipines. This agreement was in flagrant contradiction to the treaty the United States had signed with the king of Korea in 1883 providing for mutual aid in case of foreign intervention. In the name of "Realpolitik" the United States forfeited its role as protector of Korea. A step which would leave the Korean nation a prey to Japanese imperialism. ${ }^{13}$

Japanese colonialism in Korea and Taiwan was very intensive in comparison to the Western model. Although the role of the two colonies varied during different periods, their main functions were of a classical nature: that of supplying Japan with raw materials and foodstuffs while providing markets for Japanese manufactures as well as investments. Even though some industrialization did take place, especially in Korea, this was not unrelated to the ambitions of Japan to expand on the mainland and reach out for Manchuria. In contrast to other colonial relationships, the short distance between Japan and its colonies enabled the metropole to create a kind of regional political economy. ${ }^{14}$ Its primary organizational prinćiple lay in fulfilling the needs of the metropole. There can be little doubt that without the preconditions which colonialism was able to establish, such as access to cheap foodstuffs at critical moments, availability of a market when internal demand was slack, utilization of cheap labor and investment opportunities when capital was in excess, the dynamics of Japanese industrial capitalism would have been different. ${ }^{15}$

The colonies constituted a hinterland and a prerequisite for Japan's attempt to establish an exclusive Asian co-prosperity sphere in opposition to the West. The ideological attitude of the Japanese upper classes (nobility, middle and upper ranks of government and military, academics and Imperial University students) toward the outside world was dictated by nationalist assertiveness and Pan-Asianism. As formulated by Michio Morishima:

They came to feel sympathy for the nations of Asia, while at the same time despising them; increasingly they harboured a sense of obligation that Japan must take arms against Britain, America and other world powers in order to assist these Asian nations. ${ }^{16}$

As such the project of liberating the area from Western encroachment was not one of anti-imperialism but one of counter-imperialism. ${ }^{17}$ In the event, the Western powers lost their colonies, but these in turn became sub- 
jugated by a new master. The principal aim was the projection of Japanese military and economic power in Asia.

The attempt to withdraw this area from the Western influence came into conflict with two forces: One was related to the aspirations of the local populations who under the influence of nationalism refused to accept this form of internationalism. The other was the refusal of the United States, the European colonial powers as well as Australia and New Zealand, to accede to Japanese ambitions as these now threatened their own interests.

In summary the accession of the only non-European nation to the rank of industrial imperialist power was the result of specific historical circumstances which saved the country from becoming an object of colonialism. In order to avoid this fate the Japanese political elite used the "breathing space" efficiently for turning their nation into a leading imperialist contender prior to the Second World War.

\section{An American Dilemma: The Revival of Japan's Economy}

Defeat in the war closed one chapter while opening a new one in Japan's ascendancy toward economic leadership. In the following decades the fate of the country became closely intertwined with the hegemonic course of the United States. This nation, which prior to the war had been reluctant to involve itself actively in the management of the global political economy after the decline of Britain, now found itself to be the leader of world capitalism. Leadership meant responsibility not only for salvaging the system from immediate potential dangers caused by the socio-economic disruptions of the war, but for creating an international political economy which could neutralize latent contradictions between the main capitalist actors. Elements within the political establishment realized that these conflicts of interest in the 1930s had brought about the war. Under the impulse of American policy, friends and former foes were "moulded" into a political and economic alliance while the former ally, the Soviet Union, became the adversary.

This American course was a partial result of the change of administration following the sudden death of the war-time president. With Franklin. Delano Roosevelt at the helm, the US attitude had been characterized by a punitive approach toward the defeated Axis Powers and a benevolent predisposition toward the USSR. At the Teheran Conference (December 1943), the American president had hinted to Joseph Stalin that the Soviet 
Union could expect to be rewarded for eventual participation in the military defeat of Japan. During the war, the Soviet Union and Japan had adhered to a treaty of mutual neutrality. Now on the eve of victory of the antifascist coalition, Soviet interest lay in a return of the territories Tsarist Russia had lost in the Russo-Japanese War in 1905. There is evidence to suggest that as late as the Yalta Conference in February 1945 a secret understanding between Roosevelt and Stalin emerged whereby, as a quid pro quo for an early Soviet entry in the war against Japan, the United States would acquiesce in special Russian privileges in Manchuria as well as a return of the South Sakahlin and the Kuriles to the jurisdiction of the USSR. ${ }^{18}$

Similar goodwill between the two leaders dominated with regard to the approaching defeat of Nazi Germany: the American president agreed to a Soviet request for German reparations of approximately twenty billion dollars. Understanding was reached on that occasion that this question would be settled once the apparatus for the administration of Germany had been put into place.

President Roosevelt and his closest advisers had been working on the so-called Morgenthau Plan whose main intention was the transformation of Germany into a country with a "pastoral" economy unable to participate in future wars. A similar scheme was in the pipeline with regard to Japan. However, following the demise of Roosevelt and the dropping of the atomic bomb on Japan - with the purpose of keeping the USSR out of the administration of the defeated power -the basis of the Cold War was laid. Another contributing element was of course Soviet policy in Eastern Europe. Under these circumstances, the influence of the faction within the American polity in favor of harsh punishment for the Axis Powers was giving way to those favoring a rapid restoration of their economies. Another influential factor was the realization that without recovery in Europe and Japan, sustaining these societies would entail significant American sacrifices.

The dilemma was the result of a complex set of circumstances. The other capitalist economies had been devastated or disorganized during the war and these countries were facing potential social disturbances. Shortages of food and raw materials as well as industrial goods could only be overcome through American deliveries. Without hard currency to pay for such supplies these countries were experiencing a "dollar gap." With the return of peace, the United States, whose production capability had been mobilized to the outmost during the conflict, soon had to cope with the question of 
outlets once the domestic pent-up demand of the war years for consumer durables had been satisfied. US economic assistance to Europe (Marshall Plan) and to Japan (Economic Recovery in Occupied Areas) aimed at resolving both problems: foreign deficiencies and American surplus production capacity. As Richard J. Barnet writes with regard to the Marshall Plan, its real significance "which helped change the face of Europe, was not that the Americans were either altruistic or self-serving - they were both - but that the survival of the economic system in the richest nation on earth was perceived to require a systemic transfer of resources." ${ }^{\prime 19}$

The war had not only weakened the productive capacity of Europe and Japan, it affected the former external linkages which had permitted sustained industrial production. The European colonial powers were losing their "over-seas territories," while Germany's dependence on Eastern Europe as a supplier of natural resources and markets was being shattered because of the division of Europe. The liberation struggle taking place in Asia following the defeat of the Japanese "Co-Prosperity Sphere" project did not permit optimism as to the rekindling of the economies of the metropoles on the basis of a return to colonialism. As seen from Washington, rather than growing into centers of economic activity and recovery the areas of Europe, Asia and Japan seemed destined to become burdens on American "philanthropy" if not given access to earning the means to buy American goods. A course of benign neglect would have been politically prohibitive in the short and medium term. But assistance for the recovery of the other capitalist nations was bound sooner or later to translate into corresponding weakening of the position of the United States.

At the time, the options were limited. In the immediate postwar years, American expenditures involved in sustaining Japan were reaching alarming proportions. As a consequence the assistance program became geared to reestablishing the economic vitality of the country. It was felt that the revitalization of Japan would also contribute to improving the regional economic climate, the fate of Southeast Asia being another concern to US policy makers. Prior to the Second World War the area had been of importance to both European and Japanese capitalism. Now the political mood in the region was one of nationalism and anti-imperialism. Under these circumstances, the Policy Planning Group under the leadership of the architect of containment toward the Soviet Union, George Kennan, planned to encourage moderate forces with the intention of establishing an international division of labor which would contribute to the functioning of the 
economies of the allies in Europe and Japan. According to the group's recommendations, once the politics of the region had stabilized, the Unites States should vigorously seek to

develop the economic interdependence between Southeast Asia as a supplier of raw materials, and Japan, Western Europe and India, as suppliers of finished goods, with due recognition, however, of the legitimate aspirations of Southeast Asian countries for some diversification of their economies. ${ }^{20}$

The CIA concurred as to the significance for the United States of "retaining access to Southeast Asia for its own convenience and because of the great economic importance of that area to Western Europe and Japan.."21

The task of finding an harmonious equation whereby all would gain was not an easy one. In the US scheme, Southeast Asia was chosen as a kind of hinterland for Japan which would provide markets for textiles and other light industrial exports in exchange for raw materials thus alleviating the Japanese "dollar gap." This policy, however, antagonized the old colonial powers in the region, Britain and France; nor did it satisfy the aspirations of the nationalist movements. They were prepared neither for a European return nor for the reintroduction of the Japanese. The course toward Japan to a certain extent soured Anglo- American relations. Although a member of the Occupation Powers, the British had not been given any say of importance in the policy of reestablishing the Japanese economy. Britain's position had been split between fear of both recovery and collapse. It was felt that a dysfunctioning Japanese economy might deflect US resources from Europe and slow down the recovery of Southeast Asia, while a revitalized Japan might take a commanding position in the area. Not only was the region an important market, but its exports were providing significant earnings for England to help finance its trade deficit with the United States. American preoccupations with giving Japan the possibility of earning dollars in what was considered a sterling area was seen as upgrading the strengthening of Japan at the expense of the interests of the British Empire. ${ }^{22}$ In addition, countries of the area such as Australia, New Zealand, the Philippines and China were apprehensive of US policy, fearing a stimulation of Japan's imperialist appetite. Among British cabinet members and Foreign Service officials, American policy appeared as a "strange neo-imperialism of a mystical and irrational kind" combined with a "drive 
for exports which has acquired a certain force of desperation." ${ }^{23}$

Within Japan, the Occupation authorities turned monetary and trade policies in the direction of favoring Japanese exports. The American business experts in charge called for the end to the reparations Japan had been made to pay to its neighbors, as well as for the deconcentration of the economy and the democratic reforms. In December 1948, Detroit banker, John Dodge, with experience in the administration of Germany's economic reconstruction, was appointed special ambassador to Japan. As the "Czar" of the Japanese economy, he was responsible for the so-called "Dodge line" which in essence resembled the German austerity program. A good portion of stringent neo-classical economics and central controls was applied, the intention being one of turning Japan into a low-cost big industrial exporter to Asian countries. As in the German case, the immediate step was to reduce Japanese inflation and impose restrictions on consumption with priority given to building an export-oriented industry. The achievement of higher productivity was sought by reducing the number of non-competitive small and medium-size enterprises and keeping the wage level down through political means, i.e. the repression of organized labor. The resulting unemployment and social costs of this course were considered secondary to the goal of getting Japan to pay its way by becoming a large exporter. ${ }^{24}$

Not unlike the policies of prewar Japan, the "Dodge line" favored large corporations in order to take advantage of economies of scale and the promotion of exports through competitive production costs in order to penetrate the markets of Southeast Asia. Although American policy-making was dominated by liberals and free-traders, it is noteworthy that the Ministry of International Trade and Industry (MITI) was set-up during the occupation in 1949, thereby giving an additional boost to a partnership of government and business. This alliance was a return to the Japanese model of industrial development characterized by state interventionism which has existed ever since the Meiji Restoration. In addition to these measures taken under the supervision of the Occupation Administration, the exchange value of the yen was established at the low rate of 360 to the dollar, thus giving Japan an additional trading advantage.

The aim of American policy was not only the revival of the Japanese economy, but the creation of a regional political economic entity comprising the United States, Japan and Southeast Asia. The intention was to establish a relationship of economic interdependence between the three 
entities while providing, in the political sphere, a counterweight to Communism and the beginning "roll-back" of Soviet influence in the area. This construct, with the United States as the leading unit (core), Japan as the intermediate zone (semi- periphery) and Southeast Asia as the hinterland (periphery) was conceived during deliberations of the National Security Council leading to Document NSC $48 .{ }^{25}$

While Japan was looked upon as a potential junior economic partner in the region, supplying the material support for American policy in the Far East, the intention was not one of turning Japan into a competing center. The American assumption of responsibility for the fate of the defeated power consisted in giving Japan access to supplies of raw materials and markets for its production, that is, a kind of recreation of the old "Greater East Asian Co-Prosperity Sphere." But this did not imply that the United States would give up all means of leverage over Japanese developments. In 1949, during a round table conference, Geoge Kennan elaborated on the necessity of devising a formula which would fulfill these two aims: stimulating Japanese economic growth while keeping the former enemy subordinated to US interests. The key to making Japan prosperous economically and politically dependent was seen in maintaining the capability to apply pressure on the lifeline of Japan. That is the ability to excercise control over Japanese vital imports such as food, oil, etc. In the view of Kennan, by means of such an economic leash "we could have veto power over what she does." 26

\section{The Impact of the Korean War}

Notwithstanding the policies carried out by the Occupation in collaboration with the Japanese authorities to put the country on its feet again during the 1945-50 period, it was not until the Korean War that the economy began to show improvement. Politically, that conflict opened the possibility of signing a peace treaty between the United States and Japan. With its signature in 1951 the Occupation administration came to an end. From the summer of 1950, Japan's industrial capacity became solidly harnessed to serve American policy in the region. Japan became the main supplier to the US war effort in Korea, thus resolving an otherwise huge problem of logistics.

By subsidizing Japan's industrial rearmament, these procurements had a beneficial effect on the Japanese economy. The scope of the military 
orders during 1951-52 reached nearly US\$800 million per day. By the end of 1954 nearly US $\$ 3$ billion had flown into Japan while for the rest of the 1950s, funds from the new Mutual Security Program as well as the Foreign Operations Administration continued the stream of financial support for the Japanese economy. Furthermore, stable orders from the American military, together with technological transfer as well as assistance, permitted the spread of know-how to a large segment of the population while creating a favorable economic climate. As a student of this period of Japanese history points out:

These expenditures not only helped balance the still chronic dollar gap and compensated for the barriers on trade with China, but they created for the first time since 1945 an assured market for heavy industrial and high technology exports for which no other customer existed. ${ }^{27}$

At the outbreak of the Korean War, Japan's manufacturing output was a mere one-third of its 1931 level ${ }^{28}$ while in 1951 industrial production exceeded the prewar volume for the first time. ${ }^{29}$ The importance of the injection of American money and technology together with the market thus created is recognized for the contribution it made to the "take off" of Japan's "economic miracle." Michael Schaller notes the importance ascribed to this conjunction by Japanese journalists reminiscing about this period in the 1970s. They acknowledged how "even today Japanese businessmen shudder at the thought of what might have happened if there had been no war in Korea at the time." The war-stimulated boom showed itself to be quite critical for subsequent growth and stabilization of the economy. The governor of the Bank of Japan went as far as to describe the procurement program as "Divine Aid." ${ }^{30}$

The Korean War not only had a significant impact on Japan, but it contributed to shaping international developments. With the end of the Marshall Plan in June 1950, the capitalist world economy was finding itself in a kind of limbo. The Western European countries were suffering from stagnation. In the United States, the Truman Administration was being frustrated by a Congress unwilling to approve long-term assistance to Europe. Under the conditions of decreasing demand, the war resolved the dilemma by gearing Western economies to policies of rearmament. Although the trend had emerged through the climate created by the Cold 
War, the Korean conflict exacerbated the tendency of increasing weapons production. As noted by G. and J. Kolko: "...with astonishing swiftness (the war) wiped out the economic dilemmas and political restraints confronting Western capitalism during the preceding years..." ${ }^{\prime 31}$

The impact of the war economy on the Western world was unequal with regard to economic benefits. For the United States, the resulting boom created by the conflict once again brought about some semblance of prosperity. For the defeated powers of World War II, the Korean conflict contributed to their long-term accession to economic might. As Germany and Japan were resticted by their political status which did not allow rearmament policies, they were able to concentrate on producing and exporting non-military goods.

American politicians recognized the significance of the war in the Far East for the state of the world economy. As Secretary of State Dean Acheson put it, "Korea came along and saved us.." ${ }^{\prime 32} \mathrm{~A}$ remark which reflected comprehension for the need to create sufficient demand for the productive capacity of the Western economies. The weakness of the global economic construct which the United States attempted to establish in the post-World War II era was related to these objective constraints. Indeed, the options at hand were limited. First priority had to be given to a return to near-normal conditions of Europe and Japan. The revival of their economies was a guarantee for the social status quo and avoidance of political upheavals. It must be remembered that socialist forces were rather strong especially in European countries such as France and Italy. But also in Japan there was a trend within the labor movement against a return to prewar politics and against a pro- American posture. Another compelling influence on US room of maneuver was the dependence of American prosperity on the markets of those countries. Consequently, in order to give them the means to buy American goods in the short run, the United States had to contribute to the rebirth of potential competitors in the longer run.

\section{The Question of Market: Absorption of Japanese Production}

Although access to raw materials was a major concern, it was the worries about outlets which came to dominate. As a by-product of the restoration of production at higher levels of productivity this problem was recognized as a source of difficulties at that time. Thus, prior to the outbreak of the 
Korean War, Secretary of State Dean Acheson made the point that "more productive power" was now in existence "than there are markets to buy the stuff." 33

The war in Asia to a certain extent alleviated the dilemma, but the Cold War and the "loss of China" worked in the opposite direction. Because of the embargo policy, whereby the United States attempted to restrain its allies from economic intercourse with the Soviet- bloc countries, ${ }^{34}$ the situation became serious in the years following the Korean War. Prior to the conflict, Japanese statesmen had shown awareness of the necessity of developing relations with the large Chinese neighbor. This inclination was based purely on "Real- ökonomik"(!) Prime Minister Shigeru Yoshida expressed the essence of Japanese pragmatism to an American journalist in the spring of 1949: "I hate communism so much I avoid even reading about it," but in the economic context, he did not "care whether China is red or green. China is a natural market, and it has become necessary for Japan to think about markets." ${ }^{35}$ At the time, according to common understanding, political and business circles would, following a formal peace treaty with the United States, pressure the government to follow an independent regional policy not necessarily in accord with the objectives of the United States or the Soviet Union. The same year, the Japanese trade minister confirmed such an intention by stating that Tokyo was hoping to conduct from one fourth to one third of its foreign trade with Mainland China.

Influencing East Asian politics in this period was the American obsession with the China-issue. Not only had the country been "lost" to the communist revolutionaries, but US military forces had been humiliated on the Korean battlefield by the so-called "Chinese volunteers." In the early 1950s the Republican Party, dominated as it was by the active "China Lobby," was unrelentant in its determination to punish the "ungrateful" Chinese who had turned their backs on American philanthropy! Being a realist, Prime Minister Yoshida considered China as a part of Japan's economy and held the opinion that the Chinese market would not be cut off eternally. The Japanese Prime Minister was no less ideologically disinclined toward Communism than American politicians, but he did not believe that a course of isolating China would contribute to the downfall of the regime and bring about the restoration of capitalism. Instead Yoshida favored a policy of integrating Mainland China into the regional economy. At US insistance however, Japan was forced under the CHINCOM secret agreement of 1952 to impose a stricter boycott of China than was the case 
for members of the North Atlantic Treaty Organization. ${ }^{36}$

The restoration of Japan's sovereignty through the San Francisco Peace Treaty together with the armistice in Korea did not resolve the impasse of American policy in the area. The fear that an independent Japan might, in one way or another, reestablish links with the Chinese regime on the mainland led to a US policy of military isolation of China as well. The American attitude was also at odds with the other members of the Western alliance. Both the European countries and Japan resented the US-imposed restrictions on trade with China. The British, especially, eager to deflect Japanese commerce from the Sterling-bloc area in Southeast Asia, viewed the China-question differently than the Americans. The Japanese as well were much more interested in trading with both China and the West in order to acquire hard currency, rather than relying on the countertrade arrangements between Japan and the region which the United States hoped to establish. Of influence was the fact that Japanese goods in the 1950s and 1960s were considered to be of inferior quality and uncompetitive in the West. Japan was regarded as incapable of producing marketable exports. This was the gist of the message Secretary of State John Foster Dulles gave Prime Minister Yoshida in the summer of 1954: Do not place too much hope on the American market because "the Japanese don't make the things we want." Instead Dulles suggested that Japan find outlets elsewhere, i.e. in the developing world, especially in Southeast Asia. ${ }^{37}$

These circumstances explain the reluctance of Japanese politicians to follow the policy of the United States on the issue of the China-embargo. Another source of discordance was related to the US change of heart on the question of defense capability. At the instigation of General MacArthur, Article 9 of the Japanese Constitution had prohibited Japan from engaging in armament production and war preparations. This measure had been in conformity with the upsurge of Japanese pacifism following World War II. But very soon thereafter, the American position shifted toward a reversal. During a visit to Japan in 1953, Vice-President Richard Nixon publicly declared that the MacArthur contribution to the constitution, the anti-war provision, had been an error.

As seen by the Eisenhower Administration, the strategy of keeping Japan within the orbit of the West depended on two elements. Namely, trade issues and the defense question with the latter as the key link. Military buildup was seen as a method of mobilizing a certain amount of Japanese industrial production while opening the way for Japan to share 
in the burden of keeping law and order in the region. But rearmament on the scale demanded by the American side was resisted by the Japanese government, on the ground that because of domestic pacifist opinion this would not be possible. Such an evolution, Prime Minister Yoshida maintained, would have to come about as the result of a gradual process.

The question of trade was equally difficult to handle. In Washington, the mood was changing with the awareness of the limits of the power and capability of the United States to shape a world economy which could be advantageous to both the allies and to American interests. Concern with budget balancing - leading to a reduction of foreign assistance - as well as the fear of competition from Japanese and European producers were beginning to make themselves felt. Simultaneously, the US position of antagonism toward China prevented Japan from trading with the Communist regime. President Eisenhower recognized some of the contradictory aspects of a policy based on the above considerations. In his opinion, its application could yield short-term advantages but in the longer term might prove to be counterproductive; that is, the creation of a situation in Asia which American strategy was trying to prevent from arising: the loss of Japan. Under these circumstances finding outlets for Japanese exports was an issue of paramount importance. In the words of President Eisenhower during a press conference in 1954:

Japan cannot live and Japan cannot remain in the free world unless something is done to allow her to make a living. Now, if we will not give her money, if we will not trade with her, if we will not allow her to trade with the Reds ... what is to happen to Japan? It is going to the Communists. ${ }^{38}$

Disagreement on this issue existed at the highest level of the American administration. Secretary of State John Foster Dulles favored the opening of the US market to Japanese exports in order to reduce Japan's interest in the China connection, while the president, fearing a flooding of the country with Japanese goods, held an opposite view. During a cabinet meeting in August 1954, President Eisenhower argued that Japan ought to engage in trade with neighboring communist areas. This would in his opinion also serve to weaken the socialist system: 
If China, for example, finds that it can buy cheap straw hats, cheap cotton shirts, sneakers, bicycles, and all the rest of that sort of stuff from Japan it would seem to me that that would set up the need within China for the dependence upon Japan... Anyone who say that to trade with a Red country is in effect advocating a traitorous act just dosn't know what he is talking about. ${ }^{39}$

Japanese access to the Chinese market did not materialize until the complete reversal of US policy in Asia following the defeat in Indochina. In the second half of the 1940s and in the 1950s, the United States, notwithstanding its commitment to an open world economy under the banner of free trade, was not disposed to accept Japanese commerce with China. Instead, Washington acted as Japan's broker in Europe. The logic being that if the Japanese could not find takers for their wares in European countries, their cheap products would flood the United States and there would be little chance of keeping them at bay from the Chinese markets in the longer run. In part, this problem of Japanese competition had been self-inflicted. Apart from banning Japan from the Chinese market, the United States had shown, from the early postwar years, a great degree of permissiveness toward Japan's use of discriminating practices and tight control of economic exchanges. In essence these measures were similar to those that had characterized Japan's foreign economic relations prior to World War II. As Richard Barnet puts it:

Even as she was being initiated in the US designed free-trade system for the capitalist world, Japan was developing the mercantilist approach that would bring her extraordinary returns. The state guided international trade, limiting imports to the barest essentials and subsidizing exports, just as in the prewar period. ${ }^{40}$

Indeed the Japanese economy under American aegis was able to show remarkable successes. With a higher growth rate than Germany, Japan acquired an industrial capacity beyond and above internal demand. Accentuating this trend, domestic policies and the cultural background did not encourage consumerism to the same extent as in Western societies. The country was thus able to institutionalize a substantial rate of internal savings and investments leading to productivity increases.

As the same author notes, the Japanese were taking the game of eco- 
nomics very seriously and applying the lessons which American policies had introduced. Determined to catch up and come out of the bind which defeat had meant, there was little flinching:

For the Japanese, like the Germans, the world trade competition, a deadly serious business, was also a morality play. Should not the followers of Benjamin Franklin's precept benefit from their industry? Had not the United States during the occupation taught those values even if it had forgotten them. ${ }^{41}$

Besides the advantages of being an economic protégé of the United States, American security protection together with the militarization of Taiwan and especially South Korea saved Japan from the burden of a defense effort. ${ }^{42}$ Japan's strong economic performance and the relatively weak militarization of its economy meant that the country was not encumbered to the same degree by non-productive waste of resources as was the case for others. It has been estimated that had Japan from 1954 to 1974, like the United States, used 6 to 7 percent of its Gross National Product on defense, the size of its economy in 1974 would have been 30 percent smaller. ${ }^{43}$ It was not until the middle of the 1980 s that military spending in Japan creeped slightly above 1 per cent of GNP. Nevertheless, it is expected that Japan may soon become the fourth biggest military spender in the world after the U.S., the Soviet Union, and the United Kingdom.

\section{Perspectives: Adapting to Post-American Hegemony}

With hindsight, the case can be made that US policy toward Japan and East Asia in general contributed to turning Japan into the problem-child of the present world economy. It is ironical that even prior to the official surrender, Japanese business leaders rejoiced at the prospect of the United. States assuming responsibility for the future evolution of Japan. One such personality, Fujiyama Aiichiro, later to become foreign minister, reminiscing about this period, recalls that upon learning who the occupying power would be "many industrialists uncorked their champagne bottles and toasted the coming of a new industrialist era." ${ }^{\prime \prime 4}$

In a similar vein, the country's first postwar prime minister, Shigeru Yoshida, recognized the advantage of political and economic subjugation to the United States. In contrast to those favoring neutrality and object- 
ing to US domination, he half-jokingly reminded an American Embassy official of the analogy between his country's situation with regard to the United States and that of the American colonies' subordination to British colonialism. Like the Americans who later became the hegemonic power of the Atlantic Community, he remarked sarcastically, "if Japan becomes a colony of the United States, it will eventually become the stronger." ${ }^{45}$

That the United States has now become weaker is an accepted fact. The world capitalist system has since the 1970 s been suffering from economic difficulties created in essence by the increasing competition between the United States and its political allies. In retrospect, it can be said that the US scheme of establishing a new international order based on its hegemony but advantageous to all members of the Western alliance was bound to be illusory. Uneven development between the different leading nations would eventually lead to the ascendancy of those that were best able to adjust their society to the opportunities of the international system. The American project rather than retard the process perhaps accelerated it. The relationship which the United States attempted to establish comprised multifarious aspects which would eventually undermine it.

The security dimension, with time, became a significant element behind the economic problems which arose. While spending much of its resources and energy on military preparations in the confrontation with the Soviet Union, during the Cold War and the "hot wars" on the Asian continent as well as policing the rest of the world, the United States was in fact exhausting itself. In the meantime, this global politico-military posture alleviated the defence concerns of the allies as well as resolving somewhat the absorption problem of the world capitalist economy as the American market became the largest in the world. Simultaneously, US corporations took advantage of the extraordinary opportunities abroad by investing in foreign countries often with the aim of exporting the final products to the United States. This further weakened the competitive position of the United States.

These elements in combination with American international economic policies and aid programs were crucial to the so-called golden age of capitalism. A period characterized by the boom in world trade and capital flows during the 1950s and 1960s. From the present perspective of the United States, the course followed may have been too successful for its own good. As a student of US-Japanese economic relations put it: "One of the most serious weaknesses in the postwar international economic order 
was the failure to foresee, recognize and adjust to the unexpectedly rapid increase in Japanese and European industrial competitiveness relative to the United States. ${ }^{\prime 46}$

By the early 1970s, the United States experienced the first foreign trade deficit in a century. The "American Challenge," although not entirely a "paper tiger," was revealing itself to be less of a threat than some would have had the world believe. ${ }^{47}$ The world economy, under US dominance until then, was increasingly being challenged by European and Japanese contenders. Their comparative advantages were the result of lower production costs and higher productivity besides not having to contend directly with the burdens of being the international gendarme. Awareness of this evolution in the West-West balance of forces has, in recent years, giving rise to a period of American self-doubt. Richard Barnet notices a qualitative change in the US political mood toward allies as

the familiar underpinnings of a world that could be benevolently managed from Washington were crumbling. Now, in the midst of the Vietnam tragedy, the Japanese who had been part of the backdrop of world politics, suddenly became visible, and their appearance on center stage produced a certain panic in Washington. ${ }^{48}$

The point to understand with regard to the American project of revitalizing the other capitalist nations after World War II is that there was no viable alternative. Having rejected President Roosevelt's vision of a SovietAmerican condominium to run the world ${ }^{49}$ which would have been to the detriment of Europe and Japan, postwar US politicians chose the opposite course: rehabilitation of the other capitalist powers and antagonism towards the Soviet Union. In one of his last writings in 1952, Joseph Stalin predicted a dialectical shift in the West-West relationship. ${ }^{50}$ While orthodoxically emphazising the "oppressive" character of American domination on its allies, he was oblivious to the fact that "benevolence" of the United States toward former enemies and friends was actually contributing to the contradictions which would eventually emerge.

Compared with earlier examples of international hegemony, the United States altered the functioning of such a relationship. The American restructuring of the world political economy after the Second World War did contain hegemonic aspects of domination. But at the same time US policy offered opportunities to the other actors. As Bruce Cumings has noted: 
"The very breadth of this international system - its non-territoriality, its universalism, and its open systems (within the grand area) - made for a style of hegemony that was more open than previous imperialisms to competition from below." ${ }^{51}$

Perhaps better than any other nation within the Western alliance Japan was able to adjust to opportunities available. The country had historical experience to build on. It will be recalled that ever since the Meiji Restoration, Japan had shown a profound understanding of the workings of the international system. In its relationship to the outside Japan can be said to have gone through four phases: 1) resistance to the opening of the country by the West followed by selective imports of technology and other knowhow; 2) an expansionist or imperialist period in an attempt to colonize East and Southeast Asia, thus challenging the West on its own turf; 3) participation in the Second World War which signified its first defeat in the world system since its ascendancy; 4) postwar reconstruction and establishing itself as an economic superpower.

The outcome of the last phase is uncertain and the question of quo vadis gives cause to worries both inside and outside Japan. The nation finds itself at the end of three intertwined epochs: 1 ) the end of the exceptionally rapid postwar economic growth; 2) the decline of the American hegemonic position; and 3) the completion of a process which took less than one and a half century: "catching up with the West." This goal has been a driving force of Japanese nationalism. During this evolution Japan could selectively choose Western technology and other practices; and it had a model to emulate. This does not mean that Japanese society which emerged through modernization was a simple replica of the West. But in the present situation, where the nation has reached the highest economic and technological levels, Japanese society will have to innovate. Given its integration in the world economy, the Japan which will merge in the coming decades will remain internationalist. As two analysts of that country conclude: "Catching-up does not imply that Japan will henceforth become inward-looking. It is simply that Japan perceives that it must now find its own way in a highly interdependent world as the new era unfolds." ${ }^{22}$

Although Japan is presently an important actor in the world economy, its weight in the international community in the cultural and political sphere is limited. Although an economic giant, Japan is still a political dwarf! In this respect, should the country want to play an increasing world role it may have to develop a corresponding internationalist ideology. Japan's 
main ideological motivation in the modern era has been a kind of "defensive Nationalism for the sake of survival" based on Confucianism and Shintoism ${ }^{53}$ but lacking universal appeal. In practice, however, the defensive nationalism of Japan turned into aggressiveness in the process of catching up with the West. As a result its "Pan-Asianism" in the 1930s did not call forth a sympathetic response from Asians nor did many Japanese believe in it. As Johan Galtung points put:

The nationalism implicit in Shinto not only defines Japan as a center, but also the rest of the world, easily as a resource - very different from the corresponding mix in China that certainly defines China as a center, but the rest of the world more as barbarians. ${ }^{54}$

Although this culturalist approach might lead to wrong conclusions about Japan's ability to play an international role, the argument can nevertheless be made that because of this lack of universalism, Japan compares unfavorably with other world players. In the contemporary epoch, for example, the Western leading nations project the principles of democracy and Christianity, the Soviet Union uses Marxism-Leninism, while Arab nations refer to Islam. Regardless of the fact that this may be rhetorical such ideological discourse does have an internal as well as an external function. Without an ideology of universal quality, Japan can easily be accused of conducting foreign economic relations exclusively in the pursuit of selfish ends. There might be envy of Japan's acquired status and wealth, but it is questionable whether this is accompanied by admiration or real trust in Japan as a leader. As a French scholar put it "the Japanese have no natural friends, no natural allies." ${ }^{55}$ But on the other hand who has!

This does not mean however that the outside world remains immune to Japan's macro- and microeconomic successes. In the beginning of the 1980s there has been a kind of "Japanolatry" to use the expression coined by Ronald Dore. ${ }^{56}$ Industrial policy has become a subject of studies with some economists suggesting that the United States ought to emulate the Japanese. ${ }^{57}$ Similarly Japanese management techniques have become a source of interest in America. ${ }^{58}$

Nearer at home, in the East Asian region, the Japanese example exerted a significant influence on the political economies of the four "japoncitos" or Japan's Japans as Johan Galtung calls the four East Asian NICs. Similarly ASEAN countries have attempted to adopt the so-called "look East" 
economic strategies in order to learn from the Japanese case.

But until recently, Japan has not tried to establish its hegemony in the Western sense. As Galtung puts it:

Japan apparently practices a purely economic imperialism, not trying to make other countries into political, military and cultural peripheries through client formation in general, bases and alliance patterns, and cultural penetration - thereby looking more innocuous, less like a massive threat to local autonomy. ${ }^{59}$

There is no doubt that Japanese decision-makers are also aware of the impression Japan made during the colonial epoch and the earlier attempt at creating a sphere of influence in the area.

Of more determining importance to Japan's future world role will be the shape of US-Japanese ties as this relationship will be affected by the evolution of their internal situations as well as their respective national interests. It has been stated that the tie between the two countries is characterized by economic interdependence (and rivalry) and mutual dependence on the security plan. But the question is whether the partnership can survive a continuation of this type of economic and strategic relationship. ${ }^{60}$ These relations between the two countries instead of being part of the solution are in fact part of the problem. In essence, the Japanese-American relationship since the Second World War was based on the acceptance by both countries of the stabilizing influence of American dominance.

It is the axiom of the theory of "hegemonic stability" (Kindleberger, Gilpin) that in order to avoid anarchy, the international system needs a predominant power to provide the economic, political and military backing for the capitalist order. Among core-nations, the hegemon defends the rules of international intercourse by allowing its national currency to be used as the standard of exchange as well as keeping its domestic market open. According to this school of political economy, it was precisely the breakdown of Pax Britannica, with no willing or able replacement to British hegemony, which led to the anarchy of the 1930 s and the resulting conflict between the members of the international community. Aware of the horrendous disorder which the last hegemonic turnover brought in its wake before stability was again obtained under American dominance, some analysts have launched the idea of a dual US-Japanese condominium to manage the present unstable world system. A former MITI 
official has suggested a "Pax Ameripponica" based on a corporation model with the United States serving as president and Japan as vice-predident.The American magazine Time seems to prefer the neologism "Pax Amerinippon" with a division of labor entailing Japan functioning as the world's banker and the United States as its policeman.

The Japan-scholar John W. Dower who discusses this scenario considers such a construction as being out of touch with reality because of the political and psychological problems involved:

For the United States and Japan to institute even a diluted version of this Draconian agenda would require governments committed to serious structural reform and capable of marshaling a consensus in both the private and public sectors. No one really believes this is possible in either country. ${ }^{61}$

At present the United States and Japan are, for different reasons, destabilizing factors in the world economy. In order to reestablish some form of coherence in their relationship, both societies would have to change their ways of doing things. While Americans spend more than they produce, the reverse is the case for the Japanese. Thus Americans would have to consume less, export more and save more. Japanese, on the other hand, should produce less, export less, save less and consume more. On the macroeconomic level, the United States should give up adherence to the "invisible hand" and go over to some form of industrial policy in some sectors. Japan ought to abandon the "plan rationality" (Chalmers Johnson) of state interventionism in industrial policy and go over to embracing Adam Smith. The United States would have to regain superiority in high technology for strategic purposes while Japan would have to share such technology. Furthermore, for interdependence to turn into real coordination between the United States and Japan, they would have to accept a bilateral currency and mutually compatible tax systems. Chalmers Johnson insists that such ideas belong to the realm of "economic fiction." ${ }^{\prime 2}$

At present, the United States is taking initiatives to limit Japanese gains on the American market while "Japan-bashing" in the media and among academics has gained acceptability because, among other things, of the socalled "free-ride" as far as the discrepancy in defense efforts is concerned. How far can the American side push Japan to change its winning formula in world economic competition without altering qualitively the partner- 
ship and rekindling anti-Western nationalism? Such tendencies are present in Japanese society and due to the difficulties the governing Liberal Democratic Party has been facing the trend has even been reinforced. As the New York Times correspondent in Tokyo writing in the summer of 1989 put it: "Until recently, such nationalistic themes have usually been voiced only on the far left and right of Japanese politics. But now, in the midst of Japan's biggest upheaval in 35 years, a growing impatience with the United States is bubbling to the surface of mainstream political discussion." ${ }^{13}$ The tendency to say "no" to the United States is thus becoming part of the Japanese political discourse and "America-bashing" is a popular topic for prominent writers who find readily access to popular publications. $^{64}$

There is no doubt that the disharmonious state of the US-Japanese connection is having an impact on Japan. Equally important, though, are the tendencies in the world economy which are a source of worry for the Japanese elite. The growth of protectionism and the potential disintegration of free trade are seen in the creation of the Single European Market after 1992 and the United States-Canada free trade agreement. Prospects of a "European Fortress" and "North American Stockade" are taken seriously in Japan. It is a paradox of contemporary capitalism that while the internationalization of capital and production is taking place a trend toward cartelization of trade is simultaneously emerging. Confronted with the Orwellian scenario of bloc confrontation, the Japanese - besides internationalizing their economy by investing in Europe and North America - are likewise pursuing the aim of establishing a "Yen Bloc" in East Asia. The countries of the region are being submitted to a pull and push effect. Feeling attracted by the economic dynamism of Japan and rejected by the creeping protectionism of the Western capitalist world, Asian countries seem to be reluctantly willing to accept Japanese leadership in the integration of the region. As the Economist put it in a survey of the area, Japan is the key:

When the geese migrate, they fly in a V-formation. The pattern is a favorite analogy of Japanese civil servants for the economic development of East and Southeast Asia. Japan leads. Behind it follows the NICs. In the third rank are the new NICs and coastal China. As with flying geese, the arrangement is purposeful, wellordered and co-ordinated. ${ }^{65}$ 
It is not uninteresting to note that Australia is pushing in the same direction. While not disagreeing with the prospect of a replay of the Asian coprosperity scheme as a most plausible option for Japan, the American economist Rudiger Dornbusch, extrapolating from the economic strength of Japan, reaches the conclusion that in its search for more substantial outlets for investment, technology and capital goods, Japan will find a willing taker in Mikail Gorbachev's USSR. There is potential compability between the two economies as strong as the one present in the US-Japanese partnership:

In the coming era of mercantilism, money and markets count most. The Soviet Union and Japan can derive great benefits from commercial alliance: One has natural resources and untapped markets, the other has technology and capital; one wants to save, the other needs to spend. The Soviet Union and Japan are as natural a future match as America and Japan are a current match. ${ }^{66}$

The American economist may be overstating his case in an attempt to call attention to the disorder Japan's economic succes is creating for the rest of the world. But the reduction of East-West tension will further decrease the need for US strategic protection and might give Japan greater freedom of movement with regard to the Soviet Union.

In the zero-sum game of uneven capitalist development, Japan's gains amount to other countries' losses. This creates unrest for the entire system as well as for the individual members of the international community. The way Japan will adjust to the new political order is bound to open a new chapter in the country's relationship to the outside world. But of equal importance will be how the rest of the world perceives Japan's role.

The dialectics, national and international, which had such importance in Japan's ascension still operate. Until now the country has benefitted from its ties to the United States and the capitalist world system. A number of American and Japanese decision - makers would probably favor a return to the former state of the relationship: that is the stability created by American hegemony as it manifested itself before the beginning of the 1970s. The dilemma, however, is that the task of looking after all the parts of the whole system no longer is within the range of the capability of the United States. Consequently, the conjunction of American decline and Japanese ascension is an unsettling element for their bilateral relations as well as for the rest of the world. 
Jacques Hersh is Professor in Development Studies and International Relations, Aalborg University.

\section{NOTES}

1 D. Williams, "Beyond Political Economy: A Critique of Issues Raised in Chalmers Johnson's MITI and the Japanese Miracle," East Asia, No. 3, 1985.

2 For a critical discussion of attempts at conceptualizing the Japanese socioeconomic evolution since World War II, see Chalmers Johnson, MITI and the Japanese Miracle, (Stanford: Stanford University Press, 1982); Williams, "Beyond Political Economy: A Critique of Issues Raised in Chalmers Johnson's MITI and the Japanese Miracle" and Tage Bild, "Den japanske udviklingsstat," in GRUS, No. 18, 1986.

These works discuss critically principally two approaches:

a) The universalist which looks at economics as relatively autonomous systems outside of the political and cultural spheres. In so doing, AngloAmerican concepts, categories and economic behaviorism theories are applied disregarding main differences. Thus the emphasis on the market as a universal economic tool while Japanese political economy has taken the imperfection of the market as a central element behind government interventionism.

b) The culturalist approach is favored by anthropologists and humanists who emphasize the idea of "national character," "basic values" and "consensus" etc. in the explanation of the "Japanese miracle." Thus, the tendency to stress the uniqueness of that society and culture. A trend which the Japanese themselves have encouraged. (John Galtung, "On the Possible Decline and Fall of Japan. The limits to trancendence of contradictions," East Asia, Vol. 1, 1983).

3 Jon Halliday, A Political History of Japanese Capitalism (New York: Monthly Review Press, 1975), pp. 14-15, see also references 4 and 8 below.

4 E.H. Norman, "Japan's Emergence as a Modern State," in John W. Dower, ed., Origins of the Modern Japanese State, Selected Writings of E.H. Norman (New York: Pantheon Books, 1975), p. 153.

5 Ibid.

6 Michio Morishima, Why Has Japan "Succeeded"? Western Technology and the Japanese Ethos (Cambridge: Cambridge University Press, 1982), pp. 58-59.

7 Halliday, A Political History of Japanese Capitalism, p. 17.

8 Frances V. Moulder, Japan, China and the World Economy (Cambridge: Cambridge University Press, 1977), p. 130.

9 Norman, "Japan's Emergence as a Modern State," p. 154.

10 Morishima, Why Has Japan "Succeeded"? Western Technology and the Japanese Ethos, p. 16.

11 Jean-Pierre Lehmann, "Mutual Images," in Loukas Tsoukalis \& Maureen White, eds., Japan and Westem Europe (London: Frances Pinter, 1982), p. 22.

12 Norman, "Japan's Emergence as a Modern State," p. 305.

13 Robert T. Oliver, The Truth About Korea (London: Putnam, 1951), p. 99.

14 Bruce Cumings, "Northeast Asian Political Economy," International Organisation, Vol. 38, No. 1 (Winter 1984).

15 Ellen Brun \& Jacques Hersh, Socialist Korea - A Case Study in the Strategy of Economic Development (New York: Monthly Review Press, 1976), chapter 2. 
16 Morishima, Why has Japan "Succeeded"? Western Technology and the Japanese Ethos, p. 142.

17 The term counter-imperialism is borrowed from Richard Lowenthal writing on the Soviet Union's role in the Third World. See Richard Lowenthal, Model or Ally? The Communist Powers and the Developing Countries (New York: Oxford University Press, 1977), Chapter 8.

18 Michael Schaller, The American Occupation of Japan - The Origins of the Cold War in Asia (New York/Oxford: Oxford University Press, 1985), p. 7.

19 Richard J. Barnet, The Alliance: AmericaEurope-Iapan - Makers of the Postwar World (New York: Simon \& Schuster, 1983), p. 120.

20 Quoted in Schaller, The American Occupation of Japan, p. 160.

21 Quoted in Cumings, "Northeast Asian Political Economy," pp. 18-19.

22 See David E. Calleo \& Benjamin M. Rowland, America and the World Economy (Blomington: Indiana University Press, 1973), pp. 198-202.

23 Schaller, The American Occupation of Japan, p. 100.

24 See Gabriel \& Joyce Kolko, The Limits of Pozver (New York: Harper \& Row, 1972), p. 522.

25 See Cumings, "Northeast Asian Political Economy," p. 19.

26 Quoted in Schaller, The American Occupation of Japan, p. 179.

27 Ibid., p. 288.

28 Kolko, The Limits of Power, p. 642.

29 G.C. Allen, A Short Economic History of Modern Japan (London and Basingstoke: Macmillan Press, 1981), p. 190.

30 See Schaller, The American Occupation of Japan, p. 289.

31 Kolko, The Limits of Power, pp. 630-31.

32 Quoted in Cumings, "Northeast Asian Political Economy," p. 20.

33 Quoted in Schaller, The American Occupation of Japan, p. 241.

34 Gunnar Adler-Karlsson, Western Eco- 49 See David P. Calleo, Beyond American nomic Warfare (Stockholm: Almquist \& Wicksell, 1968)

35 Quoted in Schaller, The American Occupation of Japan, p. 189.

36 See Barnet, The Alliance: America-Europe-Japan - Makers of the Postwar World, p. 93.

37 See H. Brands, Jr., "The United States and the Reemergence of Independent Japan," Pacific Affairs, Vol. 59, No. 3 (Fall 1986), p. 399.

38 Quoted in Ibia., pp. 387-88.

39 Quoted in John W. Dower, Empire and Aftermath: Yoshida Shigeru and the Japanese Experience, 1878-1954 (Cambridge, Mass.: Harvard University Press, 1979), p. 581.

40 Barnet, The Alliance: America-Europe-Japan - Makers of the Postwar World, p. 269.

41 Ibid., p. 306.

42 Bruce Cumings, "Power and Plenty in Northeast Asia," in World Policy Journal, Vol. 5, No. 1 (Winter 1987-88), p. 91.

43 Hugh Patrick \& Henry Rosovsky, "Japan's Economic Performance: An Overview," in Hugh Patrick \& Henry Rosovsky, eds., Asia's New Giant: How the Japanese Economy Works? (Washington, D.C.: Brookings Institution, 1976), p. 45.

44 Quoted in John D. Montgomery, Forced To Be Free: The Antificial Revolution in Germany \& Japan (Chicago: University of Chicago Press, 1957), pp. 106-07.

45 Quoted in Schaller, The American Occupation of Japan, p. 257.

46 Stephen D. Cohen, Uneasy Partnership - Competition and Conflict in US-Japanese Trade Relations (Cambridge, Mass.: Ballinger, 1985), p. 88.

47 Jean-Jacques Servan Schreiber, The American Challenge (New York: Atheneum, 1968).

48 Barnet, The Alliance: America-Europe-Japan-Makers of the Postwar World, p. $30 \%$ 
Hegemony - The Future of the Western Alliance (London/New York: Wheatsheaf Books/Basic Books, 1987), p. 30.

50 Joseph Stalin, Economic Problems of Socialism in the USSR (Peking: Foreign Language Publishing House, 1972), pp. 33-34.

51 Cumings, "Power and Plenty in Northeast Asia," p. 80.

52 Hugh Patrick and Henry Rosovsky, "The Japanese Economy in Transition," in Toshio Shishido and Ryuzo Sato, eds., Economic Policy and Development: New Perspectives (Dover, Mass, and London: Auburn House, 1985), p. 162.

53 Morishima, Why Has Japan "Succeeded"? Western Technology and the Japanese Ethos, p. 16.

54 Galtung, "On the Possible Decline and Fall of Japan. The Limits to Trancendence of Contradictions," p. 9.

55 Lehmann, "Mutual Images," p. 23.

56 Ronald Dore, Taking Japan Seriously: A 64 Ayako Doi, International Herald Tribune, Confucian Perspective On Leading Economic Issues (Palo Alto: Stanford University Press, 1987), p. 85.

57 Lester C. Thurow, "The Case for Industrial Policy in America," in Toshio
Shishido and Ryuzo Sato, eds., Economic Theory and Development (Dover, Mass. and London: Auburn House Publishing Company, 1985), pp. 225-259.

58 See William G. Ouchi, Theori Z - How American Business Can Meet the Japanese Challenge (Reading, Mass.: Addison Wesley Publishing Company, 1981).

59 Galtung, "On the Possible Decline and Fall of Japan. The Limits to Trancendence of Contradictions," p. 7.

60 Cumings, "Power and Plenty in Northeast Asia," p. 80.

61 John W. Dower, "Fear and Prejudice in US-Japan Relations," Ethics and International Affairs, Vol. 3., 1989, p. 147.

62 Chalmers Johnson, "The Japanese Political Economy," Ethics and International Affairs, Vol. 2, 1988, p. 92.

63 David E. Sanger, International Herald Tribune, August 5-6, 1988. July 17, 1989.

65 Survey, "The Yen Block," The Economist, July 15, 1989.

66 Rudiger Dornbusch, International Herald Tribune, July 19, 1989. 